\title{
PREVALENCE OF BACTERIAL VAGINOSIS IN PREGNANCY AFTER 20 WEEKS OF GESTATION
}

\author{
Pranali Ghuge1, Dattatraya Gopalghare ${ }^{2}$
}

${ }^{1}$ Senior Resident, Department of Obstetrics and Gynaecology, MIMER Medical College, Talegaon Dabhade, Pune. ${ }^{2}$ Associate Professor, Department of Obstetrics and Gynaecology, MIMER Medical College, Talegaon Dabhade, Pune.

\section{ABSTRACT}

\section{BACKGROUND}

Bacterial vaginosis (BV) is an extremely prevalent vaginal condition and the number one cause of vaginitis among both pregnant and non-pregnant women.

Aims and Objective- To study the prevalence of bacterial vaginosis in pregnancy after 20 weeks of gestation; to study the microbiology of bacterial vaginosis and antibiotic sensitivity pattern.

Study Setting- The study is carried out in the Department of Obstetrics and Gynaecology of MIMER Medical College, Talegaon Dabhade, Pune.

Study Design- Hospital based observational study.

\section{MATERIALS AND METHODS}

The present study was conducted to study the prevalence of bacterial vaginosis in pregnancy after 20 weeks of gestation and to observe its microbiology and antibiotic sensitivity pattern.

Data Analysis and Statistical Tests- All the collected data was entered in Microsoft Excel sheet and then transferred to SPSS software version 17 for analysis. Appropriate statistical tests (t-tests/ chi-square test) were applied based on type and distribution of data. P-value $<0.05$ was taken as level of significance.

\section{RESULTS}

The study included 540 cases and prevalence of bacterial vaginosis among pregnant women was (65.6\%). The prevalence among asymptomatic cases was $64.6 \%$. In 354 cases of BV, 86.7\% were asymptomatic. Coagulase positive Staph. aureus was found in $43.9 \%$ of cases. High level of resistance against Fluoroquinolones, Cephalosporins and Penicillins and good sensitivity towards Aminoglycosides was noted.

\section{CONCLUSION}

The overall prevalence of bacterial vaginosis among pregnant women is very high in our study (65.6\%). The prevalence of BV among asymptomatic pregnant women was $64.6 \%$. In 354 cases of BV 307 were asymptomatic, i.e. $86.7 \%$. We also found high level of resistance against Fluoroquinolones, Cephalosporins and Penicillins and good sensitivity towards Aminoglycosides.

\section{KEYWORDS}

Bacterial Vaginosis in Pregnancy and Antibiotic Sensitivity.

HOW TO CITE THIS ARTICLE: Ghuge P, Gopalghare D. Prevalence of bacterial vaginosis in pregnancy after 20 weeks of gestation. J. Evolution Med. Dent. Sci. 2017;6(84):5841-5845, DOI: 10.14260/jemds/2017/1269

\begin{abstract}
BACKGROUND
Bacterial vaginosis (BV) is an extremely prevalent vaginal condition and the number one cause of vaginitis among both pregnant and non-pregnant women. ${ }^{1}$ Many studies have found the prevalence of BV in pregnancy ranges from $6 \%$ $32 \%$ in general population. $2,3,4,5$ However, majority of cases are asymptomatic and go unreported and untreated.2,5 Previously considered as benign condition, BV has been related to many gynaecological conditions and complications of pregnancy including pelvic inflammatory disease, posthysterectomy vaginal cuff cellulitis, endometritis, amniotic fluid infection, preterm labour, premature rupture of membranes and possibly spontaneous abortion. $6,7,8,9,10,11$ In
\end{abstract}

Financial or Other, Competing Interest: None.

Submission 11-09-2017, Peer Review 05-10-2017,

Acceptance 11-10-2017, Published 19-10-2017.

Corresponding Author:

Dr. Dattatraya Gopalghare,

D4-301, Latis Co-op Hsg Soc,

Talegaon Chakan Road, Talegaon Dabhade,

Talmaval District, Pune-410507

E-mail: drgopalghare@yahoo.co.in

DOI: $10.14260 /$ jemds $/ 2017 / 1269$ laboratory and clinical studies, BV has been shown to ascend to the endometrium and invade the placenta, but the complete impact of this migration in terms of initial and sustained placental development and early foetal development is unclear. ${ }^{12}$ Microbes associated with BV are part of the endogenous flora of the vagina and the acquisition of BV results when there are changes of the normal flora of the vagina causing an increased prevalence of Gardnerella vaginalis, Mycoplasma hominis and anaerobic organisms and a decreased prevalence of the dominant Lactobacillus species. ${ }^{13}$

\section{Aims and Objectives}

1. To study the prevalence of bacterial vaginosis in pregnancy after 20 weeks of gestation.

2. To study the microbiology of bacterial vaginosis and antibiotic sensitivity pattern.

\section{MATERIALS AND METHODS}

The present study was conducted to study the prevalence of bacterial vaginosis in pregnancy after 20 weeks of gestation and to observe its microbiology and antibiotic sensitivity pattern. 


\section{Study Design}

Hospital based observational study.

Time Period

October 2013 to September 2015.

\section{Study Population}

The study group comprised of pregnant females ( $>20$ weeks of gestation) from the OPD and wards of this hospital.

\section{Inclusion Criteria}

All the patients coming to OPD and wards with more than 20 weeks of gestation.

\section{Exclusion Criteria}

Less than 20 weeks of gestation and active bleeding per vaginum.

\section{Methodology}

Following information was collected and examination was carried out for every patient included in this study: Age, Parity, LMP, EDD, Gestational age in weeks, Menstrual history in detail, Obstetric History, Past History and Clinical Findings like PS Examination and PV Examination were noted.

\section{Method of Collection of Specimen}

Patient in lithotomy position, Cusco's speculum is introduced and high vaginal swab is taken before PV examination. Swab is taken under all aseptic precautions. Swab is sent to Bacteriology Laboratory as early as possible or within 2 - 3 hrs. Inoculation is done on Blood Agar or MacConkey's agar or nutrient agar or Sabouraud's agar. Growth occurs after 24 $48 \mathrm{hrs}$. Identification of the organisms is done by biochemical testing. Antimicrobial susceptibility testing takes $24-48 \mathrm{hrs}$. or more.

\section{Statistical Analysis}

All the collected data was entered in Microsoft Excel sheet and then transferred to SPSS software version 17 for analysis. Appropriate statistical tests (t-tests/ chi-square test) were applied based on type and distribution of data. P-value $<0.05$ was taken as level of significance.

\section{RESULTS}

The study was done with 540 subjects.

\begin{tabular}{|c|c|c|}
\hline Age Group (Yrs.) & Number & Percentage \\
\hline$</=20$ & 081 & $15.0 \%$ \\
\hline $21-25$ & 262 & $48.5 \%$ \\
\hline $26-30$ & 119 & $22.0 \%$ \\
\hline $31-35$ & 070 & $13.0 \%$ \\
\hline$>35$ & 008 & $01.5 \%$ \\
\hline Total & $\mathbf{5 4 0}$ & $\mathbf{1 0 0 . 0 \%}$ \\
\hline Table 1. Distribution based on Maternal Age \\
\hline
\end{tabular}

\begin{tabular}{|c|c|c|}
\hline Presenting Symptom & Number & Percentage \\
\hline None & 475 & $88.0 \%$ \\
\hline White Discharge & 065 & $12.0 \%$ \\
\hline Total & 540 & $100.0 \%$ \\
\hline
\end{tabular}

\begin{tabular}{|c|c|c|}
\hline Parity & Number & Percentage \\
\hline Multigravida & 230 & $42.6 \%$ \\
\hline Primigravida & 310 & $57.4 \%$ \\
\hline Total & 540 & $100.0 \%$ \\
\hline \multicolumn{2}{|c|}{ Table 3. Distribution based on Parity } \\
\hline
\end{tabular}

\begin{tabular}{|c|c|c|}
\hline Gestational Age & Number & Percentage \\
\hline $21-25$ & 033 & $06.1 \%$ \\
\hline $26-30$ & 108 & $20.0 \%$ \\
\hline $31-35$ & 194 & $35.9 \%$ \\
\hline$>35$ & 205 & $38.0 \%$ \\
\hline Total & 540 & $100.0 \%$ \\
\hline Table 4. Distribution as per Gestational Age \\
\hline
\end{tabular}

\begin{tabular}{|c|c|c|}
\hline Per Speculum Examination & Number & Percentage \\
\hline Normal Cervix/Vagina & 384 & $71.1 \%$ \\
\hline Cervicitis & 033 & $06.1 \%$ \\
\hline Cervical Discharge & 088 & $16.3 \%$ \\
\hline Vaginitis & 033 & $06.1 \%$ \\
\hline UV Prolapse & 002 & $00.4 \%$ \\
\hline Total & 540 & $100.0 \%$ \\
\hline \multicolumn{2}{|c|}{ Table 5. Per Speculum Examination } \\
\hline
\end{tabular}

\begin{tabular}{|c|c|c|}
\hline PV Examination & Number & Percentage \\
\hline Internal Os Closed & 327 & $60.6 \%$ \\
\hline Internal Os Open & 213 & $39.4 \%$ \\
\hline Total & 540 & $100.0 \%$ \\
\hline \multicolumn{2}{|c|}{ Table 6. Per Vaginum Examination } \\
\hline
\end{tabular}

\begin{tabular}{|c|c|c|}
\hline Culture Report & Number & Percentage \\
\hline Positive & 354 & $65.6 \%$ \\
\hline Negative & 186 & $34.4 \%$ \\
\hline Total & 540 & $100.0 \%$ \\
\hline \multicolumn{2}{|c|}{ Table 7. Distribution based on Culture Report } \\
\hline
\end{tabular}

\begin{tabular}{|c|c|c|}
\hline Organism & $\begin{array}{c}\text { Number } \\
(\mathbf{n = 3 5 4})\end{array}$ & Percentage \\
\hline Coagulase positive Staph. Aureus & 237 & $43.9 \%$ \\
\hline Candida albicans & 060 & $11.1 \%$ \\
\hline E. coli & 043 & $08.0 \%$ \\
\hline Gram negative bacilli & 028 & $05.2 \%$ \\
\hline Candida non-albicans & 019 & $03.5 \%$ \\
\hline Pseudomonas & 011 & $02.0 \%$ \\
\hline Coagulase Negative Staph. aureus & 003 & $00.6 \%$ \\
\hline Citrobacter & 003 & $00.6 \%$ \\
\hline Klebsiella & 003 & $00.6 \%$ \\
\hline Proteus & 002 & $00.4 \%$ \\
\hline Streptococci & 001 & $00.2 \%$ \\
\hline Table 8. Distribution based on Type of Organism Found \\
\hline \multicolumn{2}{|c|}{}
\end{tabular}

\begin{tabular}{|c|c|c|c|}
\hline \multirow{2}{*}{ Age Group (Yrs.) } & \multicolumn{2}{|c|}{ Bacterial Vaginosis } & \multirow{2}{*}{ Total } \\
\cline { 2 - 3 } & No & Yes & \\
\hline$</=20$ & 29 & 052 & 081 \\
\hline $21-25$ & 90 & 172 & 262 \\
\hline $26-30$ & 44 & 075 & 119 \\
\hline $31-35$ & 21 & 049 & 070 \\
\hline$>35$ & 02 & 006 & 008 \\
\hline \multirow{2}{*}{ Total } & 186 & 354 & 540 \\
\cline { 2 - 3 } & $34.40 \%$ & $65.6 \%$ & $100.0 \%$ \\
\hline \multicolumn{3}{|c|}{ P-value - 0.856 } \\
\hline
\end{tabular}

Table 9. Association of Bacterial Vaginosis and Maternal Age 


\begin{tabular}{|c|c|c|c|}
\hline \multirow{2}{*}{$\begin{array}{c}\text { Presenting } \\
\text { Symptom }\end{array}$} & \multicolumn{2}{|c|}{ Bacterial Vaginosis } & \multirow{2}{*}{ Total } \\
\cline { 2 - 3 } & No & Yes & \\
\hline None & 168 & 307 & 475 \\
\hline White Discharge & 018 & 047 & 065 \\
\hline \multirow{2}{*}{ Total } & 186 & 354 & 540 \\
\cline { 2 - 3 } & $34.40 \%$ & $65.6 \%$ & $100.0 \%$ \\
\hline \multicolumn{3}{|c|}{ P-value - 0.266 } \\
\hline \multirow{2}{*}{\begin{tabular}{c} 
Table 10. Association of Culture \\
Positivity and Presenting Symptom \\
\hline
\end{tabular}}
\end{tabular}

\begin{tabular}{|c|c|c|c|}
\hline \multirow{2}{*}{ Parity } & \multicolumn{2}{|c|}{ Bacterial Vaginosis } & \multirow{2}{*}{ Total } \\
\cline { 2 - 3 } & No & Yes & \\
\hline Primigravida & 093 & 217 & 310 \\
\hline Multigravida & 093 & 137 & 230 \\
\hline \multirow{2}{*}{ Total } & 186 & 354 & 540 \\
\cline { 2 - 3 } & $34.40 \%$ & $65.6 \%$ & $100.0 \%$ \\
\hline \multicolumn{3}{|c|}{ P-value < 0.05 } \\
\hline Table 11. Association of Parity with Positive Culture \\
\hline
\end{tabular}

\begin{tabular}{|c|c|c|c|}
\hline \multirow{2}{*}{$\begin{array}{c}\text { Gestational Age } \\
\text { (Weeks) }\end{array}$} & \multicolumn{2}{|c|}{ Bacterial Vaginosis } & \multirow{2}{*}{ Total } \\
\cline { 2 - 3 } & No & Yes & \\
\hline $21-25$ & 014 & 019 & 033 \\
\hline $26-30$ & 042 & 066 & 108 \\
\hline $31-35$ & 064 & 130 & 194 \\
\hline$>35$ & 066 & 139 & 205 \\
\hline \multirow{2}{*}{ Total } & 186 & 354 & 540 \\
\cline { 2 - 3 } & $34.40 \%$ & $65.6 \%$ & $100.0 \%$ \\
\hline \multicolumn{3}{|c|}{ Pable 12. Association of Positive } \\
Culture and Gestational Age \\
\hline
\end{tabular}

\begin{tabular}{|c|c|c|}
\hline $\begin{array}{c}\text { Antibiotic Sensitivity } \\
\text { (n= 237) }\end{array}$ & Number & Percentage \\
\hline Gentamicin & 195 & $82.3 \%$ \\
\hline Vancomycin & 096 & $40.5 \%$ \\
\hline Ampiclox & 004 & $01.7 \%$ \\
\hline Ciprofloxacin & 093 & $39.2 \%$ \\
\hline Cefotaxime & 060 & $25.3 \%$ \\
\hline Cefuroxime & 126 & $53.2 \%$ \\
\hline Cefoxitin & 036 & $15.2 \%$ \\
\hline Cefepime & 005 & $02.1 \%$ \\
\hline Linezolid & 038 & $16.0 \%$ \\
\hline Amikacin & 143 & $60.3 \%$ \\
\hline Clarithromycin & 029 & $12.2 \%$ \\
\hline Oxacillin & 053 & $22.4 \%$ \\
\hline Tobramycin & 004 & $01.7 \%$ \\
\hline Lomefloxacin & 000 & $00.0 \%$ \\
\hline Table 13. Antibiotic Sensitivity of \\
Coagulase Positive Staph aureus \\
\hline \multicolumn{2}{|c}{} \\
\hline
\end{tabular}

\begin{tabular}{|c|c|c|}
\hline Antibiotic Sensitivity (n= 43) & Number & Percentage \\
\hline Gentamicin & 24 & $55.8 \%$ \\
\hline Vancomycin & 02 & $04.7 \%$ \\
\hline Ciprofloxacin & 15 & $34.9 \%$ \\
\hline Cefotaxime & 02 & $04.7 \%$ \\
\hline Cefuroxime & 16 & $37.2 \%$ \\
\hline Cefepime & 08 & $18.6 \%$ \\
\hline Amikacin & 39 & $90.7 \%$ \\
\hline Oxacillin & 14 & $32.6 \%$ \\
\hline $\begin{array}{c}\text { Lomeflox, Ampiclox, Clarithro, } \\
\text { Tobra, Cefoxitin, Linezolid }\end{array}$ & 00 & $00.0 \%$ \\
\hline \multicolumn{2}{|c|}{ Table 14. Antibiotic Sensitivity of E. coli } \\
\hline \multicolumn{3}{|l|}{}
\end{tabular}

\begin{tabular}{|c|c|c|}
\hline Antibiotic Sensitivity (n= 11) & Number & Percentage \\
\hline Gentamicin & 10 & $90.9 \%$ \\
\hline Ciprofloxacin & 1 & $09.1 \%$ \\
\hline Cefotaxime & 2 & $18.2 \%$ \\
\hline Cefepime & 10 & $90.9 \%$ \\
\hline Amikacin & 10 & $90.9 \%$ \\
\hline Lomefloxacin & 1 & $09.1 \%$ \\
\hline Tobramycin & 2 & $18.2 \%$ \\
\hline $\begin{array}{c}\text { Oxacillin, Vanco, Ampiclox, } \\
\text { Cefurox, Cefoxitin, Linezol, Clarith }\end{array}$ & 0 & $00.0 \%$ \\
\hline
\end{tabular}

Table 15. Antibiotic Sensitivity of Pseudomonas

\begin{tabular}{|c|c|c|}
\hline Antibiotic Sensitivity $(n=28)$ & Number & Percentage \\
\hline Gentamicin & 1 & $3.6 \%$ \\
\hline Ciprofloxacin & 1 & $3.6 \%$ \\
\hline Cefotaxime & 3 & $10.7 \%$ \\
\hline Cefepime & 1 & $3.6 \%$ \\
\hline Amikacin & 2 & $7.1 \%$ \\
\hline Oxacillin & 1 & $3.6 \%$ \\
\hline $\begin{array}{l}\text { Tobra, Vanco, Ampiclox, Cefurox, } \\
\text { Cefoxitin, Linez, Clarith, Lomeflox }\end{array}$ & 0 & $0.0 \%$ \\
\hline \multicolumn{3}{|c|}{$\begin{array}{c}\text { Table 16. Antibiotic Sensitivity of } \\
\text { Other Gram Negative Bacteria }\end{array}$} \\
\hline
\end{tabular}

\section{DISCUSSION}

An observational study was carried out to find the prevalence of bacterial vaginosis in pregnancy after 20 weeks of gestation and to study the microbiology of $\mathrm{BV}$ and antibiotic sensitivity pattern. BV is a shift in the vaginal ecosystem characterised by an overgrowth of anaerobes, and a decrease in Lactobacillus resulting in degradation of the natural flora that helps to keep the vaginal tissue healthy. ${ }^{14} \mathrm{BV}$ is an important gynaecological problem of childbearing age group of women worldwide. The presence of BV has consistently been shown to be a risk factor for adverse obstetric outcomes such as preterm labour and delivery, preterm premature rupture of membranes, spontaneous abortion and postpartum infections such as endometritis and caesarean section wound infections. ${ }^{15,16,17}$ The prevalence rates of BV among pregnant women vary from $6.4 \%$ to $38 \% .18,19$ The overall prevalence of BV by Gram stains Nugent scoring criteria in a study by Mengistie et al was $19.4 \% .^{20}$ The studies done in India and Denmark showed the prevalence as $20.5 \%$ and $17 \% .^{21,22}$ Lower prevalence of $\mathrm{BV}$ was reported in Burkina Faso (6.4\%), India (8.6\%), Sweden (9.3\%), Boston (11\%) and Washington (12\%). 18,23,24,25,26

In the present study, Bacterial vaginosis was seen in twothird of subjects $65.6 \%$, which was higher than reports from different sub-Saharan countries like Kenya (37\%), Botswana (38\%) and Zimbabwe (32.5\%).20,27,28 The higher prevalence of BV in our study can be explained as most of the subjects were from lower socio-economic strata. It has been shown in various studies that lower the socioeconomic status of the population, higher the incidences of BV, which may indicate health and hygiene factors play a bigger role than anticipated. ${ }^{29}$

BV is mostly present without signs and symptoms. The most common clinical sign and symptoms of BV is thin white or gray, homogeneous vaginal discharge with or without unpleasant smell. The smell of the discharge is mostly noticed after sexual intercourse.15,30,6 In the current study out of total 354 cases of BV $86.7 \%$ were asymptomatic, while only $13.3 \%$ 
complained of white discharge. This result is consistent with other studies done in different countries. ${ }^{20,6,31}$ The study results also showed that the vaginal discharge complaints by women has less value as diagnostic algorithm, because only few females reported abnormal discharge. The findings are consistent with other studies. ${ }^{27}$ Incidence of BV was 70\% in multigravida as compared to $59.6 \%$ in primigravida ( $\mathrm{p}<$ 0.05). In a similar study by Gupta et al sixty-six (67.3\%) women with BV were nulliparous, 20 (20.4\%) were primipara, 7 (7.1\%) were second para and the remaining 5 (5.1\%) were para 3 and above. ${ }^{32}$ This shows that BV is significantly seen among nulliparous women ( $p<0.001$ ). Similar association between bacterial vaginosis and nulliparity was also shown in studies by Lata et $\mathrm{al}^{21}$ and Cristiano et al. ${ }^{33}$ Most common organism in our study was $\mathrm{S}$. aureus $(43.9 \%)$ followed by candida $(14.6 \%)$, E. coli $(8 \%)$, gram negative bacilli $(5.2 \%)$ and pseudomonas (2\%). This is in contrast to a study from India by Swamy et al, where E. coli was the most common. ${ }^{34}$ Similarly, E. coli was the most common organism in a study by Dutta $\mathrm{S}$ et al from Dhaka. ${ }^{35}$ In study by Rosenstein J et al, vaginal swabs from 174 pregnant women whose vaginal flora had been evaluated by Gram's stain. Coagulase-negative Staphylococcus species were isolated from a greater number of swabs. ${ }^{36}$

Antibiotic sensitivity pattern of Staph. aureus showed that maximum sensitivity was towards Gentamicin and Amikacin, cefuroxime and vancomycin, while poor sensitivity towards penicillin group, fluoroquinolones and cephalosporins other than cefuroxime. In study by Mulu $\mathrm{W}$ et al maximum sensitivity of $\mathrm{S}$. aureus was toward Gentamicin and Clindamycin, while maximum resistance towards penicillin group. ${ }^{37}$ Similar results were also observed by Swamy et al, ${ }^{34}$ E. coli maximum sensitivity towards Amikacin and Gentamicin. Similarly, most of the other micro-organisms showed good sensitivity towards Amikacin and Gentamicin. In study by Mulu W et al, maximum sensitivity of E. coli was toward Gentamicin and Norfloxacin, while max resistance was towards Ampicillin and Amoxicillin. ${ }^{37}$ Swamy et al observed maximum sensitivity of E. coli towards Imipenems and Amikacin, while lowest towards Ampicillin and Amoxicillin. ${ }^{34}$

\section{CONCLUSION}

The overall prevalence of bacterial vaginosis among pregnant women is very high in present study (65.6\%). The prevalence of BV among asymptomatic pregnant women was $64.6 \%$. In 354 cases of BV, 307 were asymptomatic i.e. $86.7 \%$. The above results suggest that screening for BV should start in early pregnancy, which is vital for good pregnancy outcome. We also encountered high level of resistance against Fluoroquinolones, Cephalosporins and Penicillins and good sensitivity towards Aminoglycosides. We also recommend further large scale studies to find association of adverse maternal and foetal outcomes in bacterial vaginosis.

\section{REFERENCES}

[1] Rein MF, Holmes KK. Non-specific vaginitis, vulvovaginal candidiasis, and trichomoniasis clinical features, diagnosis and management. Curr Clin Top Infect Dis 1983;4:281-315.
[2] McGregor JA, French JI. Bacterial vaginosis in pregnancy. Obstet Gynecol Surv 2000;55(5 Suppl 1):S1-19.

[3] Holzman C, Leventhal JM, Qiu H, et al. Factors linked to bacterial vaginosis in nonpregnant women. Am J Public Health 2001;91(10):1664-70.

[4] Cristiano L, Coffetti N, Dalvai G, et al. Bacterial vaginosis: prevalence in outpatients, association with some micro-organisms and laboratory indices. Genitourin Med 1989;65(6):382-7.

[5] Amsel R, Totten PA, Spiegel CA, et al. Nonspecific vaginitis. Diagnostic and microbial and epidemiologic associations. Am J Med 1983;74(1):14-22.

[6] Eschenbach DA, Hillier S, Critchlow C, et al. Diagnosis and clinical manifestations of bacterial vaginosis. Am J Obstet Gynecol 1988;158(4):819-28.

[7] Abner KP, Hessol NA, Padian NS, et al. Risk factors for plasma cell endometritis among women with cervical neisseria gonorrhoeae, cervical chlamydia trachomatis, or bacterial vaginosis. Am J Obstet Gynecol 1998;178(5):987-90.

[8] Meis PJ, Goldenberg RL, Mercer B, et al. The preterm prediction study: significance of vaginal infections. National institute of child health and human development maternal-fetal medicine units network. Am J Obstet Gynecol 1995;173(4):1231-5.

[9] Hillier SL, Martius J, Krohn M, et al. A case-control study of chorioamnionic infection and histologic chorioamnionitis in prematurity. $\mathrm{N}$ Engl J Med 1988;319(15):972-8.

[10] Kurki T, Sivonen A, Renkonen OV, et al. Bacterial vaginosis in early pregnancy and pregnancy outcome. Obstet Gynecol 1992;80(2):173-7.

[11] Hay PE, Lamont RF, Taylor-Robinson D, et al. Abnormal bacterial colonization of the genital tract and subsequent preterm delivery and late miscarriage. BMJ 1994;308(6924):295-8.

[12] Peipert JF, Montagno AB, Cooper AS, et al. Bacterial vaginosis as a risk factor for upper genital tract infection. Am J Obstet Gynecol 1997;177(5):1184-7.

[13] Austin MN, Beigi RH, Meyn LA, et al. Microbiologic response to treatment of bacterial vaginosis with topical clindamycin or metronidazole. Journal of clinical microbiology 2005;43(9):4492-7.

[14] Joesoef MR, Schmid G. Bacterial vaginosis. Clin Evid 2005;13:1968-78.

[15] CDC: Bacterial vaginosis. Factsheet 2008

[16] Mullick S, Watson-Jones D, Beksinska M, et al. Sexually transmitted infections in pregnancy: prevalence, impact on pregnancy outcomes, and approach to treatment in developing countries. Sex Transm Infect 2005;81(4):294-302.

[17] Nelson DB, Macones G. Bacterial vaginosis in pregnancy: current findings and future directions. Epidemiol Rev 2002;24(2):102-8.

[18] Kirakoya-Samadoulougou F, Nagot N, Defer MC, et al. Bacterial vaginosis among pregnant women in Burkina Faso. Sex Transm Dis 2008;35(12):985-9. 
[19] Romoren M, Velauthapillai M, Rahman M, et al. Trichomoniasis and bacterial vaginosis in pregnancy: inadequately managed with the syndromic approach. Bull World Health Organ 2007;85(4):297-304.

[20] Mengistie Z, Woldeamanuel Y, Asrat D, et al. Prevalence of bacterial vaginosis among pregnant women attending antenatal care in Tikur Anbessa university hospital, Addis Ababa, Ethiopia. BMC research notes 2014;7(1):822.

[21] Lata I, Pradeep Y, Sujata, et al. Estimation of the incidence of bacterial vaginosis and other vaginal infections and its consequences on maternal/fetal outcome in pregnant women attending an antenatal clinic in a tertiary care hospital in North India. Indian J Community Med 2010;35(2):285-9.

[22] Vogel I, Thorsen P, Jeune B, et al. Acquisition and elimination of bacterial vaginosis during pregnancy: a Danish population-based study. Infect Dis Obstet Gynecol 2006;2006:94646.

[23] Dadhwal V, Hariprasad R, Mitta S, et al. Prevalence of bacterial vaginosis in pregnant women and predictive value of clinical diagnosis. Arch Gynecol Obstet 2010;281(1):101-4.

[24] Larsson PG, Fahraeus L, Carlsson B, et al. Predisposing factors for bacterial vaginosis, treatment efficacy and pregnancy outcome among term deliveries; results from a preterm delivery study. BMC Womens Health 2007;7:20.

[25] Delaney ML, Onderdonk AB. Nugent score related to vaginal culture in pregnant women. Obstet Gynacol 2001;98(1):79-84.

[26] Krohn MA, Hillier SL, Eschenbach DA. Comparison of methods for diagnosing bacterial vaginosis among pregnant women. J Clin Microbiol 1989;27(6):126671.

[27] Marx G, John-Stewart G, Bosire R, et al. Diagnosis of sexually transmitted infections and bacterial vaginosis among HIV-1-infected pregnant women in Nairobi. Int J STD AIDS 2010;21(8):549-52.

[28] Kurewa NE, Mapingure MP, Munjoma MW, et al. The burden and risk factors of sexually transmitted infections and reproductive tract infections among pregnant women in Zimbabwe. BMC Infect Dis 2010;10:127.
[29] Allsworth JE, Peipert JF. Prevalence of bacterial vaginosis: 2001-2004 national health and nutrition examination survey data. Obstet Gynacol 2007;109(1):114-20.

[30] BASHH. National guideline for the management of bacterial vaginosis. Clinical effectiveness group, British association for sexual health and HIV 2006.

[31] Ayenalem S, Yusuf L, Ashenafi M. Lactic acid bacterial vaginosis among outpatients in Addis Ababa. Ethiop J Health Dev 2010;24(3):198-204.

[32] Gupta A, Garg P, Nigam S. Bacterial vaginosis in pregnancy $(<28$ weeks) and its effect on pregnancy outcome: a study from a western UP city. Indian Journal of Clinical Practice 2013;23(11):740-8.

[33] Cristiano L, Rampello S, Noris C, et al. Bacterial vaginosis: prevalence in an Italian population of asymptomatic pregnant women and diagnostic aspects. Eur J Epidemiol 1996;12(4):383-90.

[34] Narayana-Swamy N, Ramalingappa P, Bhatara U. Antimicrobial sensitivity pattern of microorganisms isolated from vaginal infections at a tertiary hospital in Bangalore, India. International Journal of Medical Students 2015;3(1):34-9.

[35] Dutta S, Hassan MR, Rahman F, et al. Study of antimicrobial susceptibility of clinically significant microorganisms isolated from selected areas of Dhaka, Bangladesh. Bangladesh Journal of Medical Science 2013;12(1):34-42.

[36] Rosenstein IJ, Morgan DJ, Sheehan M, et al. Bacterial vaginosis in pregnancy: distribution of bacterial species in different gram-stain categories of the vaginal flora. Journal of medical microbiology 1996;45(2):120-6.

[37] Mulu W, Yimer M, Zenebe Y, et al. Common causes of vaginal infections and antibiotic susceptibility of aerobic bacterial isolates in women of reproductive age attending at Felegehiwot referral hospital, Ethiopia: a cross sectional study. BMC women's health 2015;15:42. 